\title{
The kindness of strangers? An investigation into the interaction of funder motivations in online crowdfunding campaigns
}

\author{
Joe Cox, Thang Nguyen* and Soong Moon Kang
}

\begin{abstract}
This study investigates the interaction of motivations among contributors to online crowdfunding campaigns. Based on evidence from the literature on philanthropic behaviour, we argue that funder behaviour is likely to be driven by a combination of intrinsic, extrinsic and image enhancement motivations. We undertake an empirical investigation into the relationships between these factors by analysing data from an online rewards-based crowdfunding platform. These data not only reveal the monetary values of individual contributions to fundraising campaigns, but also indicate particular combinations of motivations based on the material reward selected (if any) and the decision as to whether or not to contribute anonymously. We find that extrinsically motivated funders generally make larger contributions than intrinsically motivated funders, which does not suggest the presence of a 'crowding-out' effect given the presence of material incentives. We further show that named funders with intrinsic motivations contribute more than anonymous funders with intrinsic motivations, whereas the same pattern of behaviour is not observed among extrinsically motivated funders. The evidence from our study therefore suggests that image concerns interact with intrinsic and extrinsic motivations in different ways.
\end{abstract}

Keywords: Motivations; Interactions; Fundraising; Online; Crowdfunding

JEL Codes: D1; D6; H4; H8

* Corresponding author: Faculty of Business and Law, University of Portsmouth, Portland Street, Portsmouth, Hampshire, PO1 3DE, UK. E-mail: thang.nguyen@port.ac.uk.

Dr Joe Cox and Dr Thang Nguyen are based in the Faculty of Business and Law at the University of Portsmouth, UK. Dr Soong Moon Kang currently works at the UCL School of Management, University College London, UK. 


\section{Introduction}

The economics literature on philanthropy broadly suggests that contributors to collective fundraising activities are driven by combinations of three main factors: intrinsic, extrinsic and image enhancement motivations (Ariely et al., 2009). Intrinsic motivations, such as altruism, warm-glow or other forms of prosocial preferences (Andreoni, 1989; Harbaugh, 1998) reflect the purely internal satisfaction derived from the act of giving. Extrinsic motivations refer to the desire to acquire material rewards or other benefits, such as a $\mathrm{CD}$, t-shirt or event tickets, while image enhancement refers to concerns relating the perceptions of others and a desire to be liked and respected.

While each of these factors might serve to motivate pro-social behaviour in its own right, the relationship may also be significantly affected by their interaction. Indeed, a seminal study by Titmuss (1970) reports seemingly counter-intuitive evidence that the offer of monetary incentives for blood donations leads to a reduction in the number of donors. Benabou \& Tirole (2006) refer to this phenomenon as the 'first puzzle' in research on prosocial activity whereby "providing rewards and punishment to foster prosocial behaviour sometimes has a perverse effect, reducing the total contribution provided by agents." (p.1652). More recent empirical evidence seems to suggest that while the offer of monetary incentives might disincentivise prosocial behaviour levels (Lacetera \& Macis, 2010a; Mellström \& Johannesson, 2008), other forms of material rewards may still act as an effective motivation (Goetter \& Stutzer, 2008; Lacetera et al., 2009).

We extend this line of research by conducting an investigation into the behaviour of funders of rewards-based crowdfunding campaigns. We base our analysis on data from the website fundanything.com, which we show to be broadly representative of other online platforms in many respects. In the rewards-based crowdfunding model, funders are incentivised through the offer of a range of material (non-financial) rewards proportionate to the value of their contributions, including simple 'thank-you' notes, baseball caps, DVDs etc. However, given mixed evidence from the literature reported above, it is unclear if the offering of material incentives would be effective in increasing contributions from funders in this particular setting. Our first research question is therefore: 'To what extent is the behaviour of contributors to online crowdfunding campaigns affected by the opportunity to claim rewards'? 
Additionally, while enquiries into the interaction between intrinsic and extrinsic motivations have been long established, several other studies (Harbaugh, 1998; Andreoni \& Petrie, 2004) have sought to investigate various interactions between these factors and the desire for image enhancement. In the context of rewards-based crowdfunding, contributing money to a campaign and not claiming an available reward may be interpreted as a generous or altruistic action which improves the social image of funders. By contrast, the claiming of a reward might be considered greedy or selfish, leading to a 'signal-extraction' problem (Benabou \& Tirole, 2006) whereby the signalling value of the contribution becomes diluted (Ariely et al., 2009). Image concerns may therefore interact differently with intrinsic and extrinsic motivations, which leads to our second research question: 'To what extent is the behaviour of contributors to online crowdfunding campaigns affected by interactions of image enhancement and intrinsic/extrinsic motivations'?

Our research provides several important contributions to the literature. First, our unique data and approach to identifying implied motivations enables us to divide the funders in our dataset into two distinct groups depending upon whether a reward is claimed in return for their contribution. On this basis, we categorise funders as either being solely intrinsically motivated or at least partly extrinsically motivated. This distinction allows us to investigate interactions between intrinsic/extrinsic motivations and the desire for image enhancement. A majority of studies in this area, such as Carpenter \& Myers, 2010 and Lacetera \& Macis, $2010 \mathrm{~b}$, are only able to investigate the interactions between image enhancement and either intrinsic or extrinsic motivations, making it very difficult to form direct comparisons. Second, our work substantially extends the emerging literature on the supply-side of crowdfunding, which stands in contrast with the majority of published studies that focus almost exclusively on the demand side (e.g. Mollick, 2014; Vismara, 2016). Only a small number of studies appearing to-date (Ryu \& Kim, 2016; Cholakova \& Clarysse, 2015; Jian \& Shin, 2015) have empirically investigated motivations in crowdfunding by focusing on data at the individual funder-level, typically through the use of relatively small-scale surveys capturing subjective assessments of motivations. To the best of our knowledge, ours is the first study to objectively identify and distinguish between the underlying motivations of contributors to crowdfunding campaigns based on a large sample of observed rather than stated behaviours.

The remainder of this paper is structured as follows. Section 2 outlines the theoretical framework which underpins our analysis, where after we accordingly establish a set of specific research hypotheses in Section 3. An overview of our data and methods is provided 
in Section 4, while Section 5 presents the results and analysis from our empirical estimations. Section 6 concludes by offering a broad overview and summary of our findings, as well as implications for our understanding of motivations to participate in collective fundraising activities.

\section{Theoretical Framework}

Our research is built upon the economic theory of philanthropic behaviour, given that funders of online fundraising campaigns and reward-based crowdfunding have been argued to be similar in many respects to their offline equivalents (Bøg et al., 2012; Gerber et al., 2012). On the surface, charitable activity and volunteerism appear to be at odds with the assumptions of neoclassical economic theory, which suggests that individuals tend to behave in a way that is consistent with rational self-interest. Indeed, several economists have argued that the 'pure altruism' model offers an inadequate explanation for giving behaviour, as any increase in individual contributions would end up being offset by decreases in the contributions of others in order to maintain the socially optimal level of giving (Sugden, 1982; Andreoni, 1988). Instead, many economists tend to conceptualise donors as 'impure altruists' who are driven by a range of private as well as social motives. These private motives might include intrinsic motivations such as a 'warm glow' (Andreoni, 1990) or a sense of satisfaction (Beretti, 2011). Donors might also be motivated extrinsically through the offer of various material and tangible rewards, as well as by a desire for image and reputational enhancement (Ariely et al., 2009). Given these various private motivations for giving based around personal gain, Vestelund (2006) suggests that "at the most extreme level, the private benefit of donating is no different from that of purchasing any other private good. (p.573)"

Although each of these motivations might incentivise prosocial behaviour in their own right, it is also the case that they might interact with one another. For example, Frey (1994) argues that offering extrinsic rewards to intrinsically motivated contributors reduces the value of their altruistic feelings thus may discourage them from contributing. Beretti et al. (2013) further argue that "external incentives can change the perceptions people have about a given task, notably by turning goodwill into a market-like interaction leading to a decrease of the overall contribution" (p.3). A number of other studies go a stage further by incorporating the interactions of image motivations with intrinsic or extrinsic motivations within formal theoretical frameworks. For example, the model developed by Harbaugh 
(1998) assumes that donors are motivated by intrinsic and prestige benefits, suggesting that publically revealing the values of individual donations ultimately enhances the associated prestige benefits and serves as a motivation to make larger contributions. In the theoretical model proposed by Benabou \& Tirole (2006), the value that each individual agent attaches to their image depends on the visibility of their actions, with the presence of visible rewards casting doubt among others over the true motivations for prosocial behaviour. Following this proposition, Ariely et al. (2009) consider image enhancement to be influenced by the perception of others regarding the merits of specific activities in which the individual is engaged. Behaving pro-socially largely enhances one's image, although offering extrinsic rewards may ultimately backfire as a donors are "suspected to be acting prosocially for extrinsic rewards rather than out of intrinsic motivations" (Ariely et al., 2009, p.546). Taken together, economic theory predicts that the presence of incentives appealing to the extrinsic motivations of contributors may have the unintended consequence of 'crowding out' motivations associated with image enhancement.

\section{Hypothesis development}

\subsection{Rewards and prosocial behaviour}

Several studies find empirical evidence in support of the original arguments put forward in the seminal work of Titmus (1970). For example, Frey \& Goette (1999) show that offering rewards actually leads to a reduction in effort among volunteers, while Mellström \& Johannesson (2008) report a significant crowding-out effect of monetary incentives amongst female blood donors. Recent studies, however, suggest that the nature of the reward can influence whether it is perceived as a net incentive or disincentive. Lacetera \& Macis (2010a) report that a substantial proportion of blood donors indicate that they would stop donating if offered $€ 10$ in cash, with the effect diminishing significantly if a voucher of the same nominal value is offered. The authors suggest that donors do not appear to demonstrate a general aversion to material incentives per se, but do show a clear aversion to the offer of cash. The incentivising effect of material incentives such as lottery tickets and symbolic rewards on blood donation is also documented in Costa-Font et al. (2013), Goetter \& Stutzer (2008) and Lacetera et al. (2009). This line of evidence is in many respects consistent with the view of donations as a form of individual consumption (Fink, 2017). 
Given that the offer of material incentives in exchange for financial contributions represents the core basis of rewards-based crowdfunding (see Section 4.1 for further details), it is likely that the presence of tangible rewards will not lead to a crowding-out of funders with intrinsic motivations in this particular context. Furthermore, the offer of material rewards may lead to a relative price effect (Ariely et al., 2009), such that extrinsically motivated funders will make larger monetary contributions in order to benefit from the provision of higher-value rewards. Thus, we hypothesise that:

H1: Funders driven in whole or in part by extrinsic motivations will contribute greater monetary amounts to any given campaign compared with purely intrinsically motivated funders.

\subsection{Image motivations, reward and prosocial behaviour}

We extend our analysis to investigate the impact of a desire for image enhancement on the behaviours of funders with extrinsic and intrinsic motivations. First, consistent with the theoretical arguments presented in the previous section, evidence from the empirical literature shows that people tend to increase levels of prosocial activity in public rather than private settings due to concerns over their image. For example, Harbaugh (1998) shows evidence of significant changes in donation behaviour when organisations report the value of contributions in tiered 'bandings'. More specifically, the author reports significant increases in the proportion of donations made at the minimum amount necessary to reach a particular tier. Lacetera \& Macis (2010b) further demonstrate that pro-social activity (blood-donation) increases dramatically when agents are close to meeting the threshold for the award of a medal, although this finding only holds when medals are awarded publically. In our study, we argue that contributing to a crowdfunding project without claiming a reward signals altruistic motivations to others and may thus result in image enhancement. Intrinsically motivated contributors therefore have an opportunity to enhance their image and reputation as a result of their giving so long as they make their identity known to others. We therefore hypothesise that:

H2a: Among solely intrinsically motivated funders, those with a desire for image enhancement will contribute greater monetary amounts to any given campaign compared with funders with no desire for image enhancement. 
Second, a number of previous studies demonstrate empirically that extrinsic incentives may have a detrimental effect on prosocial behaviour because they interact negatively with image motivations. For example, Ariely et al. (2009) show that the presence of monetary incentives only leads to an increase in prosocial activity in private and not public settings, as extrinsic motivations 'crowds out' the desire for image enhancement. Carpenter \& Myers (2010) find that paying small stipends to volunteer firefighters with image concerns (identified as those with personalised licence plates) actually reduces their propensity to turn out for emergency calls. In our specific research context, contributing to a crowdfunding project and claiming a reward may result in a signal-extraction problem as outlined above, whereby others may question whether or not the contribution was motivated a desire to obtain material rewards. Contributing greater sums to a crowdfunding campaign may therefore be less likely to result in image enhancement among funders who elect to claim a reward ${ }^{1}$. We therefore hypothesise that:

H2b: Among partly extrinsically motivated funders, those with a desire for image enhancement will not contribute greater monetary amounts to any given campaign compared with funders with no desire for image enhancement.

\section{Data and Research Design}

\subsection{Data}

Crowdfunding is a process whereby the founder of a campaign raises funds from a crowd of contributors (funders), usually through the Internet. Rewards-based crowdfunding, typified by platforms such as Kickstarter and Indiegogo, is presently among the most wellknown of the four types of crowdfunding which also include donation, equity and loan-based models. Funders of rewards-based crowdfunding campaigns are given the opportunity to claim material (non-financial) incentives, including baseball caps, t-shirts, tickets, limited edition products etc., so long their individual monetary contributions exceed certain stated thresholds (Gerber et al., 2012; Tomczack \& Brem, 2013). However, funders may decline the opportunity to receive a reward to which they would otherwise be entitled. The founder of a campaign is typically only allowed to retain the monetary amount raised so long as the

\footnotetext{
${ }^{1}$ We acknowledge that funders could still enhance their image by contributing higher monetary amounts than actually needed for the reward they eventually claim. In practice, there are very few instances in our dataset (just over $2 \%$ of observations) where funders give more than the threshold amount required for a particular reward.
} 
aggregate total raised meets or exceeds a funding target established at the start of the campaign.

The dataset used in this study is gathered from rewards-based crowdfunding platform founded in 2013 known as fundanything.com. As with other rewards-based platforms, visitors to the website can elect contribute towards individual campaigns hosted by the platform with the prospect of claiming a reward in line with the value of their contribution, with the decision as to which reward to claim (if any) occurring online at the point at which the contribution itself is made. The platform reports the identity of each funder, including the individual's name and profile picture should they choose to display them, as well as the exact monetary amount they contribute to each campaign. All of this information is recorded and made publically visible on the campaign website. This practice is unique to fundanything.com, as other leading platforms (including both Kickstarter and Indiegogo) do not disclose complete information relating to individual contribution amounts and rewards claimed. As a consequence of this reporting mechanism, we are able to demonstrate empirically how the recorded contributions of funders are determined by (interactions of) their motivations, rather than relying on self-reported attitudes or stated intentions to contribute.

We used an automated program to scrape data relating to all recorded campaigns hosted on the fundanything.com website between 2013 and 2015. In order to demonstrate how fundanything.com compares with other crowdfunding sites, Table 1 contains a broad overview of key campaign performance indicators drawn from a representative sample of platforms over an equivalent time period. These statistics show fundanything.com to be broadly comparable to many other rewards-based crowdfunding sites. The number of campaigns and the proportion that successfully reach their funding goals are somewhat lower compared with the two leading platforms Kickstarter and Indiegogo, but are similar to several others such as Crowdfunder.co.uk and Rocket Hub. The average amounts raised by each campaign, as well as the size of individual contributions and the number of funders, are comparatively close to the equivalent values observed for other platforms. Altogether, the platforms level statistics suggest that fundanything.com is fairly representative of a typical small-to-medium sized crowdfunding platform and that our results should therefore have general applicability outside of this setting.

[Table 1 about here] 
Our full dataset contains records of 54,727 contributions from individual funders which have been made towards a total of 2,143 different campaigns, raising an aggregate sum of just over $\$ 4.6$ million. Brief explanations and descriptive statistics for the variables used in our analysis presented in Table 2. Alongside our dependent variable measuring individual contribution amounts ('Amount Contributed'), we also include measures of whether the individual funder is ineligible or chooses not to claim a reward ('Intrinsic Motivation'), as well as whether they choose to reveal their name ('Named'). The figures in Table 2 suggest that the proportion of funders in each category are around $39 \%$ and $74 \%$ respectively. It seems particularly noteworthy that nearly $40 \%$ of funders contribute to rewards-based crowdfunding campaigns without claiming a reward. This relatively high proportion of solely intrinsically motivated funders appears to be consistent with the findings of Allison et al. (2015), who show that intrinsic cues (appeals to altruism) appear to attract more contributors than extrinsic (business/financial) cues in the context of crowdfunding. Additionally, our dataset includes a number of controls for campaign-level characteristics, including the funding target (\$) and number of social media (Facebook) shares; both of which might plausibly affect the magnitude of contributions towards particular campaigns.

\section{[Table 2 about here]}

Figure 1 contains a graphical representation of the distribution of our dependent 'Amount Contributed' variable, reflecting the monetary value of each individual donation in descending order from highest to lowest. It can be clearly seen that the distribution is highly skewed and consists of a very small number of large contributions alongside a much larger number of comparatively smaller contributions. Due to concerns over the disproportionate impact of significant outliers, we elect to exclude contributions of $\$ 500$ or more from our analysis, which is a threshold that appears to represent a natural cut-off point in the distribution. As a result of the exclusion of these outliers, that dataset we use for our analysis consists of 53,766 observations, reducing the sample by around $1.8 \%$ compared with its original size.

[Figure 1 about here]

Our dataset also allows us to control for heterogeneity between various types of fundraising campaigns using series of additional dummy variables to reflect the fundraising categories in 
which they were listed on the fundanything.com platform. These categories serve to differentiate and organise campaigns into groupings according to the nature of the activity being funded such Art, Business, Hopes \& Dreams or Sport. A graphical representation of the distribution of both campaigns and contributions across these categories is presented in Figure 2. It can be seen that the distribution of contributions between categories is more skewed than the distribution of the campaigns. More specifically, comparatively high proportions of campaigns are listed in the 'Business' $(12.2 \%)$, 'Family Needs' $(11.9 \%)$ and 'Hopes \& Dreams' (10.3\%) categories, while 'Film \& Video' (41.3\%) and 'Business' $(24.5 \%)$ represent the categories where the most contributions are received. This disparity is a consequence of a skewed distribution of campaign performance whereby a small number of campaigns are disproportionately highly supported, which in particular accounts for the high number of contributions recorded for campaigns in the 'Film \& Video' category. Some other categories, such as 'Design' and 'Politics', contain a very small proportion of both campaigns $(0.8 \% / 0.6 \%)$ and contributions $(0.6 \% / 0.4 \%)$ respectively.

[Figure 2 about here]

\subsection{Research Design}

In terms of addressing our primary research questions, the key independent variables summarised in Table 2 reflect the implied motivations associated with each individual contribution. As indicated above, the unique reporting framework of the fundanything.com crowdfunding platform allows us to separate funders into a number of groups according to the (combinations of) motivations demonstrated by their observed behaviours. In particular, we distinguish between funders on the basis of whether or not they claim a material rewards in return for their contributions. The contributions from funders who do not claim a reward must be solely driven by their intrinsic motivations, which may include altruism and warmglow (Tonin \& Vlassopoulos, 2010) and/or playfulness and joy (Gerber et al., 2012; Cholakova \& Clarysse 2015). By contrast, funders that choose to claim a reward must be driven at least partly by extrinsic motivations. These two groups of funders respectively correspond to the 'angelic backer' and 'reward hunter' funder-types recognised by Ryu \& Kim (2016), based on self-reported motivations among a sample of 580 contributors to Korean crowdfunding campaigns. 
Similarly, we argue that anonymous funders cannot contribute to a crowdfunding campaign with the goal of enhancing their reputation, since it is impossible for them to be identified by others (Lacetera \& Macis, 2010b; Carpenter \& Myers, 2010). By contrast, funders who make a conscious choice to reveal their identities in a publically visible, online setting are demonstrating to others that they are responsible for making the contribution. These individuals must therefore be at least partly motivated by a desire to enhance their reputation with either the campaign founder, their friends, family and/or the wider crowdfunding community. Thus, we distinguish between funders who are and are not motivated by a desire for image enhancement according to whether or not they choose to reveal their names when they make a contribution.

To capture the impacts of (interactions of) motivations on funder's contributions we use two main independent variables and their interactions. More specifically, the Intrinsic variable is equal to one (zero) where funders are solely intrinsically motivated (at least partly extrinsically motivated). In making this distinction, we acknowledge that even the funders who claim a reward might still be at least partly intrinsically motivated. However, claiming a reward clearly implies that these funders must also be at least partly extrinsically motivated, clearly distinguishing them from those who do not claim any form of material reward in return for their contribution. The Named variable is equal to one (zero) if funders do (do not) reveal their name, which we interpret as at least a partial desire for image enhancement. Interactions between extrinsic, intrinsic and image motivations are captured by an interaction term (i.e. Intrinsic $\cdot$ Named), which reflects funders who we identify as being driven by both intrinsic and image motivations. Table 3 provides a summary of the potential values for each of these variables in relation to observed behaviours and their implied motivations, as well as the proportion of funders in our dataset that fall into each of these categories.

\section{[Table 3 about here]}

\section{Analysis}

\subsection{Primary Model Specifications}

It is clear from Figure 1 that the dependent variable in our analysis is highly skewed. We therefore undertake a series of Poisson regressions on the untransformed dependent variable. We favour Poisson regressions given their superiority to log regressions and, by 
using robust standard errors (Huber-White-Sandwich linearised estimators of variance), we are able to bypass the assumption that the mean of the dependent variable is equal to its variance (Gould, 2011). Another rationale for the use of Poisson regressions is that contribution amounts tend to be concentrated around significant monetary integers (e.g., $\$ 5$, \$10, \$20) and are non-negative and discrete. As such, the dependent variable is similar in many respects to count data. The output from our Poisson regression analysis is reported in Table 4.

[Table 4 about here]

The results from Specification I are consistent with our hypothesis $\mathrm{H}_{1}$ and clearly show that funders identified as being solely intrinsically motivated tend to contribute around $23 \%$ less than extrinsically motivated funders ${ }^{2}$ while holding the values of all other variables constant. In Specification II where we do not control for intrinsic motivations, we show that named funders contribute around $5 \%$ more than anonymous funders ${ }^{3}$. This same pattern also appears to hold when simultaneously controlling for intrinsic/extrinsic and image motivations in Specification III, although the magnitude of increase in contributions observed among named funders appears to decline to around $2.5 \%$. The estimated coefficient for the term capturing the interaction between intrinsically motivated, named funders included in Specification IV is positive and significant at the $1 \%$ level, while the coefficient estimate for named funders is not found to be statistically significantly different from zero. This implies that named funders with intrinsic motivations contribute around $7.3 \%$ more than anonymous intrinsic funders, while named extrinsic funders give around the same amount compared with anonymous extrinsic funders ${ }^{4}$. These findings therefore support our hypotheses H2a and $\mathrm{H} 2 \mathrm{~b}$.

We also show evidence of significant heterogeneity in amounts given to campaigns listed in different fundraising categories. Relative to the base case of campaigns in the 'Business' category, individual contributions tend to be higher across the board for other types of campaign, particularly those in the 'Design', 'Writing' and 'Funerals' categories. The differences observed between contributions received for campaigns in each category appears consistent across model specifications. Further, our regression output consistently

\footnotetext{
2 The interpretation of the dummy coefficient of -0.262 in a Poisson regression is $\left(\mathrm{e}^{-0.262}-1\right)^{*} 100=-23 \%$.

${ }^{3}\left(\mathrm{e}^{0.048}-1\right) * 100=5 \%$.

${ }^{4}$ As the estimated coefficient of the Named variable is not statistically significant in model IV, the difference of contribution between named intrinsic funders and anonymous intrinsic funders is simply equal to the estimated coefficient of the interaction term which is $\left(\mathrm{e}^{0.070}\right.$ $1)^{*} 100=7.3 \%$
} 
demonstrates that amounts contributed tend to associate positively and significantly with both the number of social media (Facebook) shares received by the campaign, as well as the size of the funding target.

For comparison, Table 5 reports the multivariate analysis of the effect of motivations on funders' contribution to campaigns using conventional ordinary least squares regressions with robust standard errors. The coefficient estimates from these regressions are largely consistent with those appearing in Table 4 and show in Specification I that intrinsically motivated funders tend to give about $\$ 12$ less towards each campaign compared with those who are extrinsically motivated. As before in Specification II, we show that named funders typically contribute around $\$ 2$ more towards campaigns compared with those who remain anonymous, falling to around $\$ 1$ more when controlling for both variables together in Specification III. The results from Specification IV, specifically the interaction term, further suggests that named funders with intrinsic motivations contribute a little over $\$ 2$ more on average compared with anonymous intrinsic funders, while named extrinsic funders are again shown to give around the same amount compared with anonymous extrinsic funders.

[Table 5 about here]

\subsection{Robustness Checks}

The results presented above are supportive of our research hypotheses. However, in order to check the robustness of our findings, we present a number of additional Poisson regressions performed on reduced sub-samples of the data in Table 6. Specifications I and II are based on sub-samples including only intrinsically and extrinsically motivated funders respectively. The results are consistent with those presented in the previous section and show that among intrinsically motivated funders, those who are named contribute around $7 \%$ more than those who remain anonymous. Conversely among extrinsically motivated funders, there is no statistically significant difference observed in the amounts contributed between named and anonymous funders. Specifications III and IV are based on sub-samples consisting of only anonymous and named funders respectively. Again, consistent with previous results, we show that funders with intrinsic motivations contribute less than those with extrinsic motivations in both sub samples. However, the magnitude of the coefficient estimates suggests that the reduction in amounts given is lower among named funders $(-21 \%)$ than among anonymous funders (-26\%). In other words, named funders with intrinsic motivations are shown to give relatively more than anonymous funders with intrinsic motivations. 
Although our dataset does not allow us to control for many sociodemographic characteristics of the funder, we are able to use the names they provide in order to imply their gender using a specialist algorithm ${ }^{5}$. Based on inputting the first names of funders exactly as they appear on the fundanything.com site, we are able to assign gender values to around $97 \%$ of the contributions recorded from named funders. We use this information to construct a dummy variable for female contributors, which we include as an independent variable in Specification V. The results show that the coefficient for funder gender is not statistically different from zero and that the other coefficient estimates remain almost exactly the same compared with Specification IV. This leads us to conclude that funder gender does not associate with any significant variations in contribution levels.

\section{[Table 6 about here]}

In addition to the above, we present a further set of regression results to demonstrate the robustness of our findings in Table 7. In these results, we elect not to report the results associated with category dummies to conserve space, given that the coefficient estimates are substantively similar to those outlined previously. In Specifications I-III, we divide the sample into sub-sections of contributions recorded for campaigns in three broad types of category; Commercial, Prosocial and Creative. In all three cases, the results are largely consistent with the main results, in that solely intrinsically motivated funders are shown to give less than partly extrinsically motivated funders. The results also show that intrinsically motivated named funders typically give more than intrinsically motivated anonymous funders. On the other hand, named extrinsic funders contribute amounts which are equal to or less than those anonymous extrinsic funders in both the Prosocial and Creative categories. Our finding that named funders with intrinsic motivations give more than anonymous funders with intrinsic motivations holds in the case of Prosocial and Creative campaigns $(+15 \%$ and $+7 \%$ respectively), but the difference is not statistically significant in the case of Commercial campaigns. This finding suggests that the behaviour of named and anonymous intrinsically motivated funders only holds for campaigns that are non-commercial in nature. Altogether, the results continue to support our research hypotheses.

Specifications IV and $\mathrm{V}$ contain subsamples of only the campaigns that were successful and unsuccessful in meeting their funding goals respectively. Among successful

\footnotetext{
${ }^{5}$ The algorithm we employ is publically accessible via the website genderize.io.
} 
campaigns, the pattern of behaviour observed above remains consistent with previous results; funders with solely intrinsic motivations contribute less than those with partly extrinsic motivations, while named funders with intrinsic motivations contribute more than anonymous funders with intrinsic motivations. We also do not find that named extrinsic funders give more than anonymous extrinsic funders. For unsuccessful campaigns, we still find that solely intrinsic funders give less than partly extrinsic funders. However, we do not find evidence of significant differences between contributions from named and anonymous funders. A likely reason for this finding is that, by definition, a significant majority of individual contributions (74\% of our dataset) are recorded for campaigns that successfully reach their funding goals, leaving a relatively smaller pool of contributions to failed campaigns.

In Specification VI, we include a measure of whether the funder includes a publically visible photo as another (potentially stronger) indicator of a desire for image enhancement. Around $5.5 \%$ of funders choose to display a photo, with almost all among this group also providing a name along with their contribution. The results are largely consistent with other specifications, showing a reduction of about $36 \%$ in the amount contributed by funders who are solely intrinsically motivated, no statistically significant change in amounts contributed by named funders and around a 7.4\% increase in contributions from named contributors with solely intrinsic motivations. We further show that where a funder includes a photograph of themselves, contributions are shown to increase by a further $8.5 \%$ on average compared with funders that do not display a photo. This finding implies that such individuals have an even stronger desire for image enhancement and contribute higher sums accordingly. Finally, in Specification VII, we report an estimation based on the full data sample, inclusive of the large outlying observations that were originally excluded. The results suggest that funders with solely intrinsic motivations contribute significantly less than those with partly extrinsic contributions, while named contributors are shown to contribute less than anonymous contributors. Unlike the original estimations, the latter estimate is found to be statistically significant. However, these results continue to show that intrinsically motivated named funders contribute around $16 \%$ more than named funders with extrinsic motivations ${ }^{6}$. The results are again supportive of our hypotheses and suggest that the inclusion/exclusion of outliers does not substantively alter the main conclusions of the study.

\footnotetext{
${ }^{6}$ Given that the Named coefficient is statistically significant and negative, the comparison between intrinsically motivated named funders and intrinsically motivated anonymous funders can be made by summing the percentage changes associated with both the Named coefficient and the interaction term, i.e. $\left(\mathrm{e}^{-0.332}-1\right) * 100=-28.3 \%+\left(\mathrm{e}^{0.365}-1\right)^{*} 100=+44.1 \%=+15.8 \%$.
} 
[Table 7 about here]

\section{Summary and Conclusion}

This study empirically investigates the motivations of contributors to rewards-based crowdfunding campaigns. Using a unique approach, funders are grouped according to their apparent motivations based upon observed behaviours, i.e. whether or not they claim a reward and/or choose to identify themselves publically. Even though a majority of funders appear motivated at least partly by material incentives, we find evidence to suggest that a significant proportion (39\%) do not claim rewards and must therefore be solely intrinsically motivated. This comparative level of 'altruistic' behaviour is somewhat surprising in the context of a crowdfunding platform designed around the rewards-based model. In addressing our first research question, we further demonstrate that partly extrinsically motivated funders tend to make larger contributions to rewards-based crowdfunding campaigns than solely intrinsically motivated funders, which does not support the prediction of a 'crowding out' effect as per Titmuss (1970), Lacetera \& Macis (2010a) and Mellström \& Johannesson (2008).

Depending on the modelling specification used, we further observe a relatively small variation in contributions from funders that name themselves publically, who are more likely to be at least partly motivated by the potential for image enhancement compared with those contributors electing to remain anonymous. However, when we include terms to capture the interaction between intrinsic and image motivations in addressing our second research question, we show pronounced differences in the role of image concerns among funders who are solely intrinsically motivated compared with those who are partly extrinsically motivated. More specifically, we show that named, intrinsically motivated funders tend to contribute significantly greater amounts towards campaigns than intrinsically motivated anonymous funders. We also show that named funders with extrinsic motivations contribute the same or lower amounts compared with anonymous funders with extrinsic motivations.

Our findings have practical implications particularly for the founders of crowdfunding campaigns. First, it is possible that the relatively high proportion of funders who elect not to claim a reward might be incentivised to do so (and hence contribute greater amounts) in the presence of a wider selection of more attractive rewards. We therefore suggest that the number and quality of rewards offered to potential funders is likely to be of vital importance 
in determining crowdfunding outcomes and should be considered carefully by funders prior to the start of a campaign. Second, although named, intrinsically motivated funders may never elect to claim a reward due to concerns over the dilution of the social value of their signal, is possible that campaign founders could elect to recognise and reward them in different ways. This might include special acknowledgements that could be linked to the funders profile and/or disseminated via social media channels to highlight that the funder has contributed to a project without claiming a reward. Given the implied motivations and behaviours of this group, the transmission of such publically visible signals is likely to be highly valued and may encourage greater quantities and/or values of contributions.

The findings of this study are consistent with theories of pro-social giving (Benabou \& Tirole, 2006; Ariely et al., 2009), whereby image enhancement tends to occur only when contributions are perceived by others as being generous, altruistic or prosocial. The rejection of material rewards signals altruistic intentions on the part of the funder and may therefore represent an essential component of the reputation-seeking behaviour associated with visible participation in online crowdfunding campaigns. Through an extensive series of robustness checks, we demonstrate that our findings hold in almost all of the different ways in which we model the data, the most notable exception being that, unlike Prosocial and Creative campaigns, the differences in behaviours observed for named and anonymous intrinsically motivated funders does not appear to hold for Commercial campaigns. This seems to imply that any possible desire for image enhancement resulting from solely intrinsically motivated contributions only holds when the cause being supported is appropriate to the altruistic behaviour being signalled. Altogether, our findings suggest that the complex range and interactions of funder motivations are important in explaining variations in behaviours and outcomes in crowdfunding, with implied intrinsic and extrinsic motivations seemingly representing valued signalling mechanisms that influence the actions of funders seeking to enhance their image. 


\section{References}

Allison, T.H., Davis, B.C., Short, J.C., \& Webb, J.W. (2015). Crowdfunding in a prosocial microlending environment: Examining the role of intrinsic versus extrinsic cues.

Entrepreneurship Theory and Practice, 39(1), 53-73.

Andreoni, J. (1988). Privately provided public goods in a large economy: the limits of altruism. Journal of Public Economics, 35(1), 57-73.

Andreoni, J. (1989). Giving with impure altruism: applications to charity and Ricardian equivalence. The Journal of Political Economy. 97, 1447-1458.

Andreoni, J. (1990). Impure altruism and donations to public goods: a theory of warm-glow giving. The Economic Journal, 464-477.

Ariely, D., Bracha, A. \& Meier, S. (2009). Doing good or doing well? Image motivation and monetary incentives in behaving pro-socially. American Economic Review, 544-555.

Beretti, A., Figuières, C. \& Grolleau, G. (2013). Using money to motivate both "Saints" and "Sinners": a field experiment on motivation. KYKLOS, 66(1), 63-77.

Bénabou, R. \& Tirole, J. (2006). Incentives and pro-social behaviour. American Economic Review, 1652-1678.

Bøg, M., Harmgart, H., Huck. S. \& Jeffers, A., M. (2012). Fundraising on the Internet. KYKLOS, 65(1), 18-30.

Carpenter, J., \& Myers, C.K. (2010). Why volunteer? Evidence on the role of altruism, image, \& incentives. Journal of Public Economics, 94(11), 911-920.

Cholakova, M. \& Clarysse, B. (2015). Does the possibility to make equity investments in crowdfunding projects crowd-out rewards-based investments. Entrepreneurship Theory and Practice, 145-172.

Costa-Font, J., Jofre-Bonet, M. \& Yen, S., T., (2013). Not all incentives wash out the warm glow: The case of blood donation revisited. KYKLOS, 66(4), 529-551.

Fink, A. (2017). Donations to political parties: Investing corporations and consuming individuals. KYKLOS, 70(2), 220-255.

Frey, Bruno S. (1994). How Intrinsic Motivation Is Crowded Out and In. Rationality and Society, 6(3), pp. 334-52.

Frey, Bruno S. \& Jegen, R. (2001). Motivation crowding theory. Journal of Economic Surveys, 15(5), 589-611.

Frey, B. S. \& Goette, L. (1999). Does pay motivate volunteers? University of Zurich, Institute for Empirical Research in Economics Working Paper, Number 7. 
Gerber, M., E., Hui, S., J. \& Kuo, P. (2012). Crowdfunding: Why People Are Motivated to Post and Fund Projects on Crowdfunding Platforms. Working paper.

Goette, L., \& Stutzer, A. (2008). Blood donation and incentives: Evidence from a field experiment. IZA Working Paper, Number 3580.

Gould, W. (2011). Use poisson rather than regress; tell a friend. Retrieved from http://blog. stata. com/2011/08/22/use-poisson-rather-than-regress-tell-a-friend.

Hamari, J., Sjöklint, M., \& Ukkonen, A. (2015). The sharing economy: Why people participate in collaborative consumption. Journal of the Association for Information Science and Technology, 67(9), 2047-2059.

Harbaugh, T. W. (1998). What do donations buy? A model of philanthropy based on prestige and warm glow. Journal of Public Economics, 67, 269-284.

Jian, L. \& Shin, J. (2015). Motivations behind donors' contributions to crowdfunded journalism. Mass Communication and Society, 18(2), 165-185.

Lacetera, N. \& Macis, M. (2010a). Do all material incentives for pro-social activities backfire? The response to cash and non-cash incentives for blood donations. Journal of Economic Psychology, 31, 738-748.

Lacetera, N. \& Macis, M. (2010b). Social image concerns and prosocial behavior: Field evidence from a nonlinear incentive scheme. Journal of Economic Behavior \& Organization, 76(2), 225-237.

Lacetera, N., Macis, M., \& Slonim, R. (2009). Increasing donations or stealing altruism? Material incentives and substitution effects in pro-social behavior, IZA DP 4567.

Mellström, C. \& Johannesson, M. 2008. Crowding out in blood donation: was Titmuss right? Journal of European Economic Association, 6(4), 845-863.

Mollick, E. (2014). The dynamics of crowdfunding: An exploratory study. Journal of Business Venturing, 29(1), 1-16.

Pitschner, S. \& Pitschner-Finn, S. (2014). Non-profit differentials in crowd-based financing: Evidence from 50,000 campaigns. Economics Letters, 123(3), 391-394.

Ryu, S. \& Kim, Y. (2016). A typology of crowdfunding sponsors: Birds of a feather flock together? Electronic Commerce and Applications, 16, 43-54.

Sugden, R. (1982). On the economics of philanthropy. The Economic Journal, 92(366), 341350 .

Titmus, R., M. (1970). The gift relationship. London: Allen and Unwin.

Tonin, M. \& Vlassopoulos, M. (2010). Disentangling the sources of pro-socially motivated effort: A field experiment. Journal of Public Economics, 94, 1086-1092. 
Vesterlund, L. (2006). Why do people give. The non-profit sector: A research handbook 2, 168-190.

Vismara, S. (2016). Equity retention and social network theory in equity crowdfunding. Small Business Economics, 46, 579-590. 


\section{TABLES AND FIGURES}

Table 1: Comparison of Reward-Based Crowdfunding Campaign Outcomes by Platform

\begin{tabular}{|c|c|c|c|c|c|}
\hline Crowdfunding Platform & $\begin{array}{l}\text { Number of } \\
\text { Campaigns }\end{array}$ & $\begin{array}{c}\text { Campaign } \\
\text { Success Rate }\end{array}$ & $\begin{array}{c}\text { Average Amount } \\
\text { Raised }\end{array}$ & $\begin{array}{l}\text { Average Indiv. } \\
\text { Contribution }\end{array}$ & $\begin{array}{c}\text { Average No. of } \\
\text { Funders }\end{array}$ \\
\hline Fundanything.com & 2,143 & $7 \%$ & $\$ 2,234$ & $\$ 74$ & 25 \\
\hline Kickstarter & 93,340 & $33 \%$ & $\$ 6,495$ & $\$ 63$ & 80 \\
\hline Indiegogo & 103,768 & $14 \%$ & $\$ 2,841$ & $\$ 53$ & 33 \\
\hline Crowdfunder.co.uk & 3,151 & $25 \%$ & $\$ 3,031$ & $\$ 58$ & 27 \\
\hline Fundrazr & 830 & $22 \%$ & $\$ 2,066$ & $\$ 96$ & 26 \\
\hline Rocket Hub & 4,114 & $6 \%$ & $\$ 831$ & $\$ 33$ & 9 \\
\hline Sponsume & 416 & $10 \%$ & $\$ 1,189$ & $\$ 32$ & 23 \\
\hline
\end{tabular}

Table 2: Descriptive Statistics

\begin{tabular}{|c|c|c|c|c|c|c|}
\hline Variable & Description & Mean & Std. Dev. & Median & Min. & Max. \\
\hline Amount Contributed (\$) & The $\$$ amount contributed by individual $i$ to campaign $j$. & 74.29 & 345.13 & 30.00 & 1.00 & 25,000 \\
\hline Intrinsic Motivation & $\begin{array}{l}\text { Dummy variable; }=1 \text { where the individual } i \text { elects not to } \\
\text { claim a reward to which they may have been entitled. }\end{array}$ & 0.39 & - & - & 0 & 1 \\
\hline Named & $\begin{array}{l}\text { Dummy variable; }=1 \text { where the individual agent } i \text { elects } \\
\text { to reveal their identity when making a contribution. }\end{array}$ & 0.74 & - & - & 0 & 1 \\
\hline Funding Target $(\$)$ & $\begin{array}{l}\text { The } \$ \text { amount that the founder of crowdfunding campaign } \\
j \text { seeks to raise. }\end{array}$ & 88,653 & 560,634 & 7,500 & 1 & $10,000,000$ \\
\hline
\end{tabular}

Table 3: Classification of Implied Motivations According to Observed Behaviours

\begin{tabular}{|c|c|c|c|}
\hline Variable Values & Observed Behaviours & Implied Motivation(s) & Proportion of Funders \\
\hline $\begin{array}{l}\text { Intrinsic Motivation }=1 \\
\text { Named }=0 \\
\text { Intrinsic } \cdot \text { Named }=0\end{array}$ & $\begin{array}{l}\text { DOES NOT claim reward } \\
\text { DOES NOT provide name or picture. }\end{array}$ & Purely intrinsic & $14.2 \%$ \\
\hline $\begin{array}{l}\text { Intrinsic Motivation }=1 \\
\text { Named }=1 \\
\text { Intrinsic } \cdot \text { Named }=1\end{array}$ & $\begin{array}{l}\text { DOES NOT claim reward } \\
\text { Provides name and/or picture. }\end{array}$ & Mix of intrinsic and image concerns & $25.1 \%$ \\
\hline $\begin{array}{l}\text { Intrinsic Motivation }=0 \\
\text { Named }=0 \\
\text { Intrinsic } \cdot \text { Named }=0\end{array}$ & $\begin{array}{l}\text { Claims reward } \\
\text { DOES NOT Provide name or picture. }\end{array}$ & Mix of intrinsic and extrinsic & $11.9 \%$ \\
\hline $\begin{array}{l}\text { Intrinsic Motivation }=0 \\
\text { Named }=1 \\
\text { Intrinsic } \cdot \text { Named }=0\end{array}$ & $\begin{array}{l}\text { Claims reward } \\
\text { Provides name and/or picture. }\end{array}$ & $\begin{array}{l}\text { Mix of intrinsic, extrinsic and image } \\
\text { concerns }\end{array}$ & $48.7 \%$ \\
\hline
\end{tabular}


Table 4: Poisson Regressions of Individual-Level Contributions Dependent Variable: Amount Contributed

\begin{tabular}{|c|c|c|c|c|c|c|c|c|}
\hline \multirow{2}{*}{$\begin{array}{l}\text { Model } \\
\text { Intrinsic Motivation }(=1)\end{array}$} & \multicolumn{2}{|l|}{ I } & \multicolumn{2}{|l|}{ II } & \multicolumn{2}{|l|}{ III } & \multicolumn{2}{|l|}{ IV } \\
\hline & -0.262 & *** & & & -0.259 & $* * *$ & -0.307 & $* * *$ \\
\hline & $(0.013)$ & & & & $(0.013)$ & & $(0.021)$ & \\
\hline \multirow[t]{2}{*}{ Named $(=1)$} & & & 0.048 & $* * *$ & 0.024 & $* *$ & -0.006 & \\
\hline & & & $(0.011)$ & & $(0.011)$ & & $(0.015)$ & \\
\hline \multirow[t]{2}{*}{ Intrinsic Motivation * Named } & & & & & & & 0.070 & ${ }^{* * *}$ \\
\hline & & & & & & & $(0.023)$ & \\
\hline \multirow[t]{2}{*}{ Ln Social Media Shares } & 0.015 & $* * *$ & 0.022 & $* * *$ & 0.014 & ${ }^{* * *}$ & 0.014 & ${ }^{* * *}$ \\
\hline & $(0.003)$ & & $(0.003)$ & & $(0.003)$ & & $(0.003)$ & \\
\hline \multirow[t]{2}{*}{ Ln Funding Target (\$) } & 0.052 & $* * *$ & 0.067 & $* * *$ & 0.052 & $* * *$ & 0.053 & ${ }^{* * *}$ \\
\hline & $(0.004)$ & & $(0.004)$ & & $(0.004)$ & & $(0.004)$ & \\
\hline \multirow{2}{*}{$\operatorname{Art}(=1)$} & 0.687 & $* * *$ & 0.800 & $* * *$ & 0.685 & ${ }^{* * *}$ & 0.688 & ${ }^{* * *}$ \\
\hline & $(0.096)$ & & $(0.096)$ & & $(0.096)$ & & $(0.096)$ & \\
\hline \multirow[t]{2}{*}{ Community $(=1)$} & 0.763 & *** & 0.721 & $* * *$ & 0.757 & $* * *$ & 0.756 & $* * *$ \\
\hline & $(0.049)$ & & $(0.049)$ & & $(0.049)$ & & $(0.049)$ & \\
\hline \multirow[t]{2}{*}{ Design $(=1)$} & 1.012 & *** & 1.155 & $* * *$ & 1.015 & $* * *$ & 1.009 & $* * *$ \\
\hline & $(0.047)$ & & $(0.048)$ & & $(0.047)$ & & $(0.047)$ & \\
\hline \multirow{2}{*}{ Education $(=1)$} & 0.841 & $* * *$ & 0.808 & $* * *$ & 0.839 & $* * *$ & 0.839 & $* * *$ \\
\hline & $(0.030)$ & & $(0.031)$ & & $(0.030)$ & & $(0.030)$ & \\
\hline \multirow{2}{*}{ Family Needs $(=1)$} & 0.810 & $* * *$ & 0.741 & $* * *$ & 0.806 & $* * *$ & 0.806 & $* * *$ \\
\hline & $(0.030)$ & & $(0.030)$ & & $(0.030)$ & & $(0.030)$ & \\
\hline \multirow[t]{2}{*}{ Film \& Video $(=1)$} & 0.491 & $* * *$ & 0.537 & $* * *$ & 0.486 & $* * *$ & 0.489 & $* * *$ \\
\hline & $(0.012)$ & & $(0.012)$ & & $(0.012)$ & & $(0.012)$ & \\
\hline Funerals $(=1)$ & 1.007 & $* * *$ & 0.971 & $* * *$ & 1.002 & $* * *$ & 1.001 & $* * *$ \\
\hline & $(0.054)$ & & $(0.053)$ & & $(0.054)$ & & $(0.054)$ & \\
\hline Gaming $(=1)$ & 0.194 & ${ }^{* * *}$ & 0.302 & $* * *$ & 0.195 & $* * *$ & 0.192 & ${ }^{* * *}$ \\
\hline & $(0.048)$ & & $(0.049)$ & & $(0.048)$ & & $(0.048)$ & \\
\hline Hopes and Dreams $(=1)$ & 0.527 & ${ }^{* * *}$ & 0.487 & $* * *$ & 0.522 & $* * *$ & 0.522 & ${ }^{* * *}$ \\
\hline & $(0.036)$ & & $(0.036)$ & & $(0.036)$ & & $(0.036)$ & \\
\hline Medical (=1) & 0.869 & ${ }^{* * *}$ & 0.815 & $* * *$ & 0.865 & $* * *$ & 0.866 & ${ }^{* * *}$ \\
\hline & $(0.033)$ & & $(0.033)$ & & $(0.033)$ & & $(0.033)$ & \\
\hline Music $(=1)$ & 0.366 & $* * *$ & 0.456 & $* * *$ & 0.363 & $* * *$ & 0.364 & $* * *$ \\
\hline & $(0.042)$ & & $(0.042)$ & & $(0.042)$ & & $(0.043)$ & \\
\hline Non-Profit $(=1)$ & 0.482 & $* * *$ & 0.439 & $* * *$ & 0.479 & ${ }^{* * *}$ & 0.479 & ${ }^{* * *}$ \\
\hline & $(0.029)$ & & $(0.029)$ & & $(0.029)$ & & $(0.029)$ & \\
\hline Pets \& Animals $(=1)$ & 0.517 & $* * *$ & 0.490 & $* * *$ & 0.513 & $* * *$ & 0.514 & ${ }^{* * *}$ \\
\hline & $(0.038)$ & & $(0.038)$ & & $(0.038)$ & & $(0.038)$ & \\
\hline Politics $(=1)$ & 0.583 & $* * *$ & 0.606 & $* * *$ & 0.583 & $* * *$ & 0.584 & $* * *$ \\
\hline & $(0.079)$ & & $(0.081)$ & & $(0.079)$ & & $(0.079)$ & \\
\hline Sports $(=1)$ & 0.615 & $* * *$ & 0.606 & $* * *$ & 0.609 & $* * *$ & 0.608 & ${ }^{* * *}$ \\
\hline & $(0.060)$ & & $(0.060)$ & & $(0.060)$ & & $(0.060)$ & \\
\hline Technology $(=1)$ & 0.334 & $* * *$ & 0.432 & $* * *$ & 0.334 & $* * *$ & 0.333 & $* * *$ \\
\hline & $(0.067)$ & & $(0.067)$ & & $(0.067)$ & & $(0.067)$ & \\
\hline Theater $(=1)$ & 0.810 & $* * *$ & 0.805 & $* * *$ & 0.804 & $* * *$ & 0.802 & $* * *$ \\
\hline & $(0.053)$ & & $(0.053)$ & & $(0.054)$ & & $(0.054)$ & \\
\hline Volunteering $(=1)$ & 0.688 & $* * *$ & 0.741 & $* * *$ & 0.684 & $* * *$ & 0.683 & ${ }^{* * *}$ \\
\hline & $(0.066)$ & & $(0.067)$ & & $(0.066)$ & & $(0.066)$ & \\
\hline Web Projects $(=1)$ & 0.477 & $* * *$ & 0.555 & $* * *$ & 0.475 & $* * *$ & 0.476 & ${ }^{* * *}$ \\
\hline & $(0.120)$ & & $(0.119)$ & & $(0.120)$ & & $(0.120)$ & \\
\hline Writing $(=1)$ & 1.349 & $* * *$ & 1.464 & $* * *$ & 1.348 & $* * *$ & 1.347 & ${ }^{* * *}$ \\
\hline & $(0.048)$ & & $(0.048)$ & & $(0.048)$ & & $(0.048)$ & \\
\hline Other $(=1)$ & 0.747 & $* * *$ & 0.764 & $* * *$ & 0.744 & $* * *$ & 0.745 & $* * *$ \\
\hline & $(0.086)$ & & $(0.085)$ & & $(0.086)$ & & $(0.086)$ & \\
\hline Constant & 2.839 & $* * *$ & 2.468 & $* * *$ & 2.826 & $* * *$ & 2.842 & $* * *$ \\
\hline & $(0.056)$ & & $(0.053)$ & & $(0.057)$ & & $(0.057)$ & \\
\hline Number of Observations & 53,766 & & 53,766 & & 53,766 & & 53,766 & \\
\hline Wald $\mathrm{Chi}^{2}$ & 4483.700 & $* * *$ & 4129.280 & $* * *$ & 4505.370 & $* * *$ & 4493.150 & $* * *$ \\
\hline Pseudo $\mathrm{R}^{2}$ & 0.093 & & 0.085 & & 0.093 & & 0.094 & \\
\hline $\begin{array}{l}\text { Dependent variable is the } \$ \text { am } \\
\text { Funding Target }(\$) \text { are respect } \\
\text { value of the fundraising target } \\
\text { 'Business' category represent }\end{array}$ & $\begin{array}{l}\text { ibuted by i } \\
\text { atural loga } \\
\text { or campaig } \\
\text { se. Robus }\end{array}$ & $\begin{array}{l}\text { divi } \\
\text { hm } \\
j . \mathrm{A}\end{array}$ & $\begin{array}{l}\text { to campaig1 } \\
\text { gregate nur } \\
\text { r variables } \\
\text { rors are in }\end{array}$ & $\mathrm{L}$ & $\begin{array}{l}\text { ial Media }( \\
\text { ial media }( \\
\text { in Table } 2 \\
* \text { p }<.10\end{array}$ & $\begin{array}{r}\mathrm{acel} \\
\mathrm{Ca} \\
\mathrm{Ca}\end{array}$ & $\begin{array}{l}\text { Shares and } \\
\text { shares an } \\
\text { gns in the } \\
\text {, *** p }<\text {. }\end{array}$ & $\begin{array}{l}\text { Ln } \\
\text { the } \$\end{array}$ \\
\hline
\end{tabular}


Table 5: OLS Regressions of Individual-Level Contributions Dependent Variable: Amount Contributed

\begin{tabular}{|c|c|c|c|c|c|c|c|c|}
\hline Model & I & & II & & III & & IV & \\
\hline Intrinsic Motivation (=1) & $\begin{array}{r}-11.760 \\
(0.552)\end{array}$ & $* * *$ & & & $\begin{array}{r}-11.602 \\
(0.557)\end{array}$ & **** & $\begin{array}{r}-13.214 \\
(0.902)\end{array}$ & $* * *$ \\
\hline Named $(=1)$ & & & $\begin{array}{r}2.363 \\
(0.527)\end{array}$ & $* * *$ & $\begin{array}{r}1.139 \\
(0.529)\end{array}$ & $* *$ & $\begin{array}{r}-0.061 \\
(0.787)\end{array}$ & \\
\hline Intrinsic Motivation * Named & & & & & & & $\begin{array}{r}2.375 \\
(1.050)\end{array}$ & $* *$ \\
\hline Ln Social Media Shares & $\begin{array}{r}0.593 \\
(0.130)\end{array}$ & $* * *$ & $\begin{array}{r}0.919 \\
(0.128)\end{array}$ & $* * *$ & $\begin{array}{r}0.589 \\
(0.130)\end{array}$ & $* * *$ & $\begin{array}{r}0.583 \\
(0.130)\end{array}$ & $* * *$ \\
\hline Ln Funding Target (\$) & $\begin{array}{r}2.601 \\
(0.185)\end{array}$ & $* * *$ & $\begin{array}{r}3.212 \\
(0.184)\end{array}$ & $* * *$ & $\begin{array}{r}2.597 \\
(0.185)\end{array}$ & $* * *$ & $\begin{array}{r}2.622 \\
(1.186)\end{array}$ & $* * *$ \\
\hline $\operatorname{Art}(=1)$ & $\begin{array}{r}30.484 \\
(4.577)\end{array}$ & $* * *$ & $\begin{array}{r}35.239 \\
(4.602)\end{array}$ & $* * *$ & $\begin{array}{r}30.388 \\
(4.579)\end{array}$ & $* * *$ & $\begin{array}{r}30.519 \\
(4.582)\end{array}$ & $* * *$ \\
\hline Community $(=1)$ & $\begin{array}{r}33.681 \\
(2.355)\end{array}$ & $* * *$ & $\begin{array}{r}31.749 \\
(2.342)\end{array}$ & $* * *$ & $\begin{array}{r}33.434 \\
(2.334)\end{array}$ & $* * *$ & $\begin{array}{r}33.402 \\
(2.332)\end{array}$ & $* * *$ \\
\hline Design $(=1)$ & $\begin{array}{r}53.184 \\
(3.534)\end{array}$ & $* * *$ & $\begin{array}{r}59.558 \\
(3.597)\end{array}$ & $* * *$ & $\begin{array}{r}53.339 \\
(3.537)\end{array}$ & $* * *$ & $\begin{array}{r}53.128 \\
(3.537)\end{array}$ & $* * *$ \\
\hline Education $(=1)$ & $\begin{array}{r}38.451 \\
(1.569)\end{array}$ & $* * *$ & $\begin{array}{r}36.903 \\
(1.590)\end{array}$ & $* * *$ & $\begin{array}{r}38.329 \\
(1.570)\end{array}$ & $* * *$ & $\begin{array}{r}38.364 \\
(1.570)\end{array}$ & $* * *$ \\
\hline Family Needs (=1) & $\begin{array}{r}35.891 \\
(1.370)\end{array}$ & $* * *$ & $\begin{array}{r}32.876 \\
(1.381)\end{array}$ & $* * *$ & $\begin{array}{r}35.689 \\
(1.376)\end{array}$ & $* * *$ & $\begin{array}{r}35.692 \\
(1.377)\end{array}$ & $* * *$ \\
\hline Film \& Video $(=1)$ & $\begin{array}{r}23.007 \\
(0.537)\end{array}$ & $* * *$ & $\begin{array}{r}25.140 \\
(0.545)\end{array}$ & $* * *$ & $\begin{array}{r}22.783 \\
(0.551)\end{array}$ & $* * *$ & $\begin{array}{r}22.903 \\
(0.556)\end{array}$ & $* * *$ \\
\hline Funerals $(=1)$ & $\begin{array}{r}46.876 \\
(3.116)\end{array}$ & $* * *$ & $\begin{array}{c}45.151 \\
(3.076)\end{array}$ & $* * *$ & $\begin{array}{r}46.657 \\
(3.111)\end{array}$ & $* * *$ & $\begin{array}{r}46.645 \\
(3.108)\end{array}$ & $* * *$ \\
\hline Gaming $(=1)$ & $\begin{array}{r}8.264 \\
(1.848)\end{array}$ & $* * *$ & $\begin{array}{r}13.086 \\
(1.860)\end{array}$ & $* * *$ & $\begin{array}{r}8.314 \\
(1.848)\end{array}$ & $* * *$ & $\begin{array}{r}8.192 \\
(1.847)\end{array}$ & $* * *$ \\
\hline Hopes and Dreams $(=1)$ & $\begin{array}{r}23.452 \\
(1.409)\end{array}$ & $* * *$ & $\begin{array}{r}21.631 \\
(1.427)\end{array}$ & $* * *$ & $\begin{array}{r}23.254 \\
(1.414)\end{array}$ & $* * *$ & $\begin{array}{r}23.269 \\
(1.414)\end{array}$ & $* * *$ \\
\hline Medical (=1) & $\begin{array}{r}38.972 \\
(1.611)\end{array}$ & $* * *$ & $\begin{array}{r}36.524 \\
(1.617)\end{array}$ & $* * *$ & $\begin{array}{r}38.812 \\
(1.612)\end{array}$ & $* * *$ & $\begin{array}{r}38.836 \\
(1.613)\end{array}$ & $* * *$ \\
\hline Music (=1) & $\begin{array}{r}16.701 \\
(1.637)\end{array}$ & $* * *$ & $\begin{array}{r}20.509 \\
(1.612)\end{array}$ & $* * *$ & $\begin{array}{r}16.566 \\
(1.638)\end{array}$ & $* * *$ & $\begin{array}{r}16.622 \\
(1.639)\end{array}$ & $* * *$ \\
\hline Non-Profit $(=1)$ & $\begin{array}{r}20.769 \\
(1.165)\end{array}$ & $* * *$ & $\begin{array}{r}18.707 \\
(1.168)\end{array}$ & $* * *$ & $\begin{array}{r}20.621 \\
(1.167)\end{array}$ & $* * *$ & $\begin{array}{r}20.618 \\
(1.167)\end{array}$ & $* * *$ \\
\hline Pets \& Animals $(=1)$ & $\begin{array}{r}23.306 \\
(1.458)\end{array}$ & $* * *$ & $\begin{array}{r}21.919 \\
(1.475)\end{array}$ & $* * *$ & $\begin{array}{r}23.123 \\
(1.463)\end{array}$ & $* * *$ & $\begin{array}{r}23.186 \\
(1.465)\end{array}$ & $* * *$ \\
\hline Politics (=1) & $\begin{array}{r}25.716 \\
(3.488)\end{array}$ & $* * *$ & $\begin{array}{r}26.355 \\
(3.577)\end{array}$ & $* * *$ & $\begin{array}{r}25.704 \\
(3.489)\end{array}$ & $* * *$ & $\begin{array}{r}25.766 \\
(3.491)\end{array}$ & $* * *$ \\
\hline Sports $(=1)$ & $\begin{array}{r}27.183 \\
(2.483)\end{array}$ & $* * *$ & $\begin{array}{r}26.572 \\
(2.507)\end{array}$ & $* * *$ & $\begin{array}{r}26.902 \\
(2.486)\end{array}$ & $* * *$ & $\begin{array}{r}26.864 \\
(2.487)\end{array}$ & $* * *$ \\
\hline Technology $(=1)$ & $\begin{array}{r}14.590 \\
(2.561)\end{array}$ & $* * *$ & $\begin{array}{c}18.978 \\
(2.572)\end{array}$ & $* * *$ & $\begin{array}{r}14.572 \\
(2.560)\end{array}$ & $* * *$ & $\begin{array}{r}14.544 \\
(2.559)\end{array}$ & ${ }^{* * *}$ \\
\hline Theater $(=1)$ & $\begin{array}{r}36.705 \\
(2.851)\end{array}$ & $* * *$ & $\begin{array}{r}36.185 \\
(2.836)\end{array}$ & $* * *$ & $\begin{array}{r}36.429 \\
(2.855)\end{array}$ & $* * *$ & $\begin{array}{r}36.378 \\
(2.856)\end{array}$ & $* * *$ \\
\hline Volunteering $(=1)$ & $\begin{array}{r}30.424 \\
(3.019)\end{array}$ & $* * *$ & $\begin{array}{r}32.324 \\
(3.028)\end{array}$ & $* * *$ & $\begin{array}{r}30.218 \\
(3.028)\end{array}$ & $* * *$ & $\begin{array}{r}30.183 \\
(3.028)\end{array}$ & $* * *$ \\
\hline Web Projects $(=1)$ & $\begin{array}{r}20.849 \\
(4.934)\end{array}$ & $* * *$ & $\begin{array}{r}24.100 \\
(4.876)\end{array}$ & $* * *$ & $\begin{array}{r}20.737 \\
(4.933)\end{array}$ & $* * *$ & $\begin{array}{r}20.806 \\
(4.934)\end{array}$ & $* * *$ \\
\hline Writing $(=1)$ & $\begin{array}{r}84.470 \\
(4.973)\end{array}$ & $* * *$ & $\begin{array}{r}89.407 \\
(5.013)\end{array}$ & $* * *$ & $\begin{array}{r}84.413 \\
(4.977)\end{array}$ & $* * *$ & $\begin{array}{r}84.416 \\
(4.974)\end{array}$ & $* * *$ \\
\hline Other $(=1)$ & $\begin{array}{c}32.988 \\
(4.070)\end{array}$ & $* * *$ & $\begin{array}{r}33.547 \\
(4.043)\end{array}$ & $* * *$ & $\begin{array}{r}32.855 \\
(4.081)\end{array}$ & $* * *$ & $\begin{array}{r}32.918 \\
(4.082)\end{array}$ & $* * *$ \\
\hline Constant & $\begin{array}{r}0.671 \\
(2.356)\end{array}$ & & $\begin{array}{r}-15.672 \\
(2.230)\end{array}$ & $* * *$ & $\begin{array}{r}-0.007 \\
(2.369)\end{array}$ & & $\begin{array}{r}0.600 \\
(2.381)\end{array}$ & \\
\hline $\begin{array}{l}\text { Number of Observations } \\
\mathrm{F} \\
\mathrm{R}^{2}\end{array}$ & $\begin{array}{r}53,766 \\
183.360 \\
0.079\end{array}$ & $* * *$ & $\begin{array}{r}53,766 \\
164.250 \\
0.073\end{array}$ & ${ }^{* * *}$ & $\begin{array}{r}53,766 \\
177.190 \\
0.079\end{array}$ & ${ }^{* * *}$ & $\begin{array}{r}53,766 \\
170.380 \\
0.079\end{array}$ & $* * *$ \\
\hline $\begin{array}{l}\text { Dependent variable is the } \$ \text { am } \\
\text { Funding Target }(\$) \text { are respecti } \\
\text { value of the fundraising target } \\
\text { Robust standard errors are in } p\end{array}$ & $\begin{array}{l}\text { uted by } i \\
\text { ural loga } \\
\text { campaig } \\
p<.10\end{array}$ & $\begin{array}{l}\text { divic } \\
\text { thms } \\
j . \mathrm{C} \\
* * \mathrm{p}\end{array}$ & $\begin{array}{l}\text { campaigr } \\
\text { egate nun } \\
\text { s in the " } \\
* \mathrm{p}<.01\end{array}$ & 1.1 & $\begin{array}{l}1 \text { Media ( } \\
1 \text { media ( } \\
\text { tegory rep }\end{array}$ & $\begin{array}{l}\text { ace } \\
\text { ace } \\
\text { ese }\end{array}$ & $\begin{array}{l}\text { hares and } \\
\text { hares and } \\
\text { ase case. }\end{array}$ & $\begin{array}{l}\text { Ln } \\
\text { the } \$\end{array}$ \\
\hline
\end{tabular}


Table 6: Poisson Regressions of Reduced Sub-Samples

Dependent Variable: Amount Contributed

\begin{tabular}{|c|c|c|c|c|c|c|c|c|c|c|}
\hline \multirow{2}{*}{$\begin{array}{l}\text { Model } \\
\text { Intrinsic Motivation }(=1)\end{array}$} & \multicolumn{2}{|c|}{$\begin{array}{c}\text { I } \\
\text { Intrinsic } \\
\text { Only } \\
\end{array}$} & \multicolumn{2}{|c|}{$\begin{array}{c}\text { II } \\
\text { Extrinsic } \\
\text { Only }\end{array}$} & \multicolumn{2}{|c|}{$\begin{array}{c}\text { III } \\
\text { Anonymous } \\
\text { Only }\end{array}$} & \multicolumn{2}{|c|}{$\begin{array}{c}\text { IV } \\
\text { Named } \\
\text { Only }\end{array}$} & \multicolumn{2}{|c|}{$\begin{array}{c}\text { V } \\
\text { Named Only } \\
\text { w/ Gender }\end{array}$} \\
\hline & & & & & $\begin{array}{c}-0.301 \\
(0.023)\end{array}$ & & $\begin{array}{c}-0.236 \\
(0.016)\end{array}$ & $* * *$ & $\begin{array}{r}-0.226 \\
(0.016)\end{array}$ & \\
\hline Named $(=1)$ & $\begin{array}{r}0.071 \\
(0.018)\end{array}$ & *** & $\begin{array}{r}-0.020 \\
(0.015)\end{array}$ & & & & & & & \\
\hline Funder Gender Female $(=1)$ & & & & & & & & & $\begin{array}{r}-0.012 \\
(0.014)\end{array}$ & \\
\hline Ln Social Media Shares & $\begin{array}{r}0.014 \\
(0.003)\end{array}$ & *** & $\begin{array}{r}0.029 \\
(0.007)\end{array}$ & ${ }^{* * *}$ & $\begin{array}{r}0.016 \\
(0.005)\end{array}$ & $* * *$ & $\begin{array}{r}0.014 \\
(0.004)\end{array}$ & *** & $\begin{array}{r}0.015 \\
(0.004)\end{array}$ & *** \\
\hline Ln Funding Target (\$) & $\begin{array}{r}0.022 \\
(0.007)\end{array}$ & *** & $\begin{array}{r}0.024 \\
(0.007)\end{array}$ & ${ }^{* * *}$ & $\begin{array}{r}0.054 \\
(0.009)\end{array}$ & $* * *$ & $\begin{array}{r}0.053 \\
(0.005)\end{array}$ & $* * *$ & $\begin{array}{r}0.053 \\
(0.005)\end{array}$ & *** \\
\hline Art $(=1)$ & $\begin{array}{r}0.398 \\
(0.157)\end{array}$ & ** & $\begin{array}{r}0.680 \\
(0.121)\end{array}$ & ** & $\begin{array}{r}0.736 \\
(0.202)\end{array}$ & $* * *$ & $\begin{array}{r}0.667 \\
(0.105)\end{array}$ & $* * *$ & $\begin{array}{r}0.676 \\
(0.109)\end{array}$ & *** \\
\hline Community $(=1)$ & $\begin{array}{r}0.567 \\
(0.057)\end{array}$ & *** & $\begin{array}{r}0.685 \\
(0.123)\end{array}$ & *** & $\begin{array}{r}0.692 \\
(0.086)\end{array}$ & $* * *$ & $\begin{array}{r}0.764 \\
(0.058)\end{array}$ & ${ }^{* * *}$ & $\begin{array}{r}0.765 \\
(0.059)\end{array}$ & *** \\
\hline Design $(=1)$ & $\begin{array}{r}-0.474 \\
(0.395)\end{array}$ & & $\begin{array}{r}1.139 \\
(0.054)\end{array}$ & & $\begin{array}{r}1.104 \\
(0.068)\end{array}$ & *** & $\begin{array}{r}0.949 \\
(0.069)\end{array}$ & $* * *$ & $\begin{array}{r}0.971 \\
(0.070)\end{array}$ & *** \\
\hline Education $(=1)$ & $\begin{array}{r}0.610 \\
(0.042)\end{array}$ & $* * *$ & $\begin{array}{r}0.913 \\
(0.049)\end{array}$ & *** & $\begin{array}{r}0.923 \\
(0.052)\end{array}$ & $* * *$ & $\begin{array}{r}0.798 \\
(0.037)\end{array}$ & $* * *$ & $\begin{array}{r}0.802 \\
(0.038)\end{array}$ & $* * *$ \\
\hline Family Needs (=1) & $\begin{array}{r}0.623 \\
(0.039)\end{array}$ & $* * *$ & $\begin{array}{r}0.288 \\
(0.095)\end{array}$ & $* * *$ & $\begin{array}{r}0.926 \\
(0.056)\end{array}$ & $* * *$ & $\begin{array}{r}0.751 \\
(0.035)\end{array}$ & $* * *$ & $\begin{array}{r}0.725 \\
(0.036)\end{array}$ & *** \\
\hline Film \& Video $(=1)$ & $\begin{array}{r}0.050 \\
(0.038)\end{array}$ & & $\begin{array}{r}0.597 \\
(0.017)\end{array}$ & & $\begin{array}{r}0.568 \\
(0.026)\end{array}$ & $* * *$ & $\begin{array}{r}0.456 \\
(0.014)\end{array}$ & ${ }^{* * *}$ & $\begin{array}{r}0.463 \\
(0.014)\end{array}$ & ${ }^{* * *}$ \\
\hline Funerals $(=1)$ & $\begin{array}{r}0.878 \\
(0.062)\end{array}$ & $* * *$ & $\begin{array}{r}0.177 \\
(0.092)\end{array}$ & $*$ & $\begin{array}{r}0.822 \\
(0.106)\end{array}$ & $* * *$ & $\begin{array}{r}1.048 \\
(0.062)\end{array}$ & $* * *$ & $\begin{array}{r}1.040 \\
(0.061)\end{array}$ & $* * *$ \\
\hline Gaming $(=1)$ & $\begin{array}{r}-0.410 \\
(0.131)\end{array}$ & *** & $\begin{array}{r}0.220 \\
(0.052)\end{array}$ & $* * *$ & $\begin{array}{r}0.306 \\
(0.084)\end{array}$ & $* * *$ & $\begin{array}{r}0.126 \\
(0.058)\end{array}$ & $* *$ & $\begin{array}{r}0.159 \\
(0.059)\end{array}$ & *** \\
\hline Hopes and Dreams $(=1)$ & $\begin{array}{r}0.289 \\
(0.048)\end{array}$ & *** & $\begin{array}{r}0.552 \\
(0.071)\end{array}$ & *** & $\begin{array}{r}0.635 \\
(0.066)\end{array}$ & $* * *$ & $\begin{array}{r}0.472 \\
(0.043)\end{array}$ & $* * *$ & $\begin{array}{r}0.489 \\
(0.044)\end{array}$ & ${ }^{* * *}$ \\
\hline Medical $(=1)$ & $\begin{array}{r}0.704 \\
(0.043)\end{array}$ & $* * *$ & $\begin{array}{r}0.408 \\
(0.063)\end{array}$ & *** & $\begin{array}{r}0.943 \\
(0.057)\end{array}$ & *** & $\begin{array}{r}0.828 \\
(0.040)\end{array}$ & $* * *$ & $\begin{array}{r}0.843 \\
(0.042)\end{array}$ & *** \\
\hline Music (=1) & $\begin{array}{r}0.320 \\
(0.073)\end{array}$ & *** & $\begin{array}{r}0.251 \\
(0.054)\end{array}$ & *** & $\begin{array}{r}0.350 \\
(0.084)\end{array}$ & $* * *$ & $\begin{array}{r}0.365 \\
(0.049)\end{array}$ & $* * *$ & $\begin{array}{r}0.382 \\
(0.050)\end{array}$ & $* * *$ \\
\hline Non-Profit (=1) & $\begin{array}{r}0.390 \\
(0.038)\end{array}$ & *** & $\begin{array}{r}0.158 \\
(0.050)\end{array}$ & $* * *$ & $\begin{array}{r}0.468 \\
(0.053)\end{array}$ & $* * *$ & $\begin{array}{r}0.483 \\
(0.034)\end{array}$ & $* * *$ & $\begin{array}{r}0.493 \\
(0.035)\end{array}$ & $* * *$ \\
\hline Pets \& Animals $(=1)$ & $\begin{array}{r}0.289 \\
(0.050)\end{array}$ & *** & $\begin{array}{r}0.432 \\
(0.079)\end{array}$ & $* * *$ & $\begin{array}{r}0.696 \\
(0.071)\end{array}$ & $* * *$ & $\begin{array}{r}0.430 \\
(0.045)\end{array}$ & $* * *$ & $\begin{array}{r}0.445 \\
(0.046)\end{array}$ & $* * *$ \\
\hline Politics $(=1)$ & $\begin{array}{r}0.168 \\
(0.133)\end{array}$ & & $\begin{array}{r}0.850 \\
(0.092)\end{array}$ & & $\begin{array}{r}0.648 \\
(0.121)\end{array}$ & *** & $\begin{array}{r}0.554 \\
(0.105)\end{array}$ & $* * *$ & $\begin{array}{r}0.569 \\
(0.110)\end{array}$ & $* * *$ \\
\hline Sports $(=1)$ & $\begin{array}{r}0.383 \\
(0.071)\end{array}$ & $* * *$ & $\begin{array}{r}0.576 \\
(0.124)\end{array}$ & $* * *$ & $\begin{array}{r}0.662 \\
(0.102)\end{array}$ & $* * *$ & $\begin{array}{r}0.580 \\
(0.071)\end{array}$ & $* * *$ & $\begin{array}{r}0.608 \\
(0.072)\end{array}$ & $* * *$ \\
\hline Technology $(=1)$ & $\begin{array}{r}0.096 \\
(0.128)\end{array}$ & & $\begin{array}{r}0.390 \\
(0.083)\end{array}$ & & $\begin{array}{r}0.300 \\
(0.095)\end{array}$ & $* * *$ & $\begin{array}{r}0.360 \\
(0.089)\end{array}$ & $* * *$ & $\begin{array}{r}0.414 \\
(0.090)\end{array}$ & ${ }^{* * *}$ \\
\hline Theater $(=1)$ & $\begin{array}{r}0.691 \\
(0.070)\end{array}$ & $* * *$ & $\begin{array}{r}0.627 \\
(0.089)\end{array}$ & *** & $\begin{array}{r}0.883 \\
(0.123)\end{array}$ & $* * *$ & $\begin{array}{r}0.768 \\
(0.060)\end{array}$ & $* * *$ & $\begin{array}{r}0.786 \\
(0.061)\end{array}$ & ${ }^{* * *}$ \\
\hline Volunteering $(=1)$ & $\begin{array}{r}0.514 \\
(0.090)\end{array}$ & $* * *$ & $\begin{array}{r}0.603 \\
(0.103)\end{array}$ & $* * *$ & $\begin{array}{r}0.925 \\
(0.144)\end{array}$ & $* * *$ & $\begin{array}{r}0.580 \\
(0.070)\end{array}$ & $* * *$ & $\begin{array}{r}0.618 \\
(0.071)\end{array}$ & $* * *$ \\
\hline Web Projects $(=1)$ & $\begin{array}{r}0.597 \\
(0.166)\end{array}$ & *** & $\begin{array}{r}0.207 \\
(0.167)\end{array}$ & & $\begin{array}{r}0.512 \\
(0.227)\end{array}$ & ** & $\begin{array}{r}0.460 \\
(0.141)\end{array}$ & ${ }^{* * *}$ & $\begin{array}{r}0.482 \\
(0.143)\end{array}$ & $* * *$ \\
\hline Writing (=1) & $\begin{array}{r}0.435 \\
(0.133)\end{array}$ & *** & $\begin{array}{r}1.468 \\
(0.055)\end{array}$ & $* * *$ & $\begin{array}{r}1.538 \\
(0.076)\end{array}$ & $* * *$ & $\begin{array}{r}1.249 \\
(0.061)\end{array}$ & $* * *$ & $\begin{array}{r}1.262 \\
(0.062)\end{array}$ & $* * *$ \\
\hline Other $(=1)$ & $\begin{array}{r}0.657 \\
(0.115)\end{array}$ & $* * *$ & $\begin{array}{r}0.399 \\
(0.098)\end{array}$ & $* * *$ & $\begin{array}{r}1.122 \\
(0.159)\end{array}$ & $* * *$ & $\begin{array}{r}0.515 \\
(0.083)\end{array}$ & $* * *$ & $\begin{array}{r}0.527 \\
(0.084)\end{array}$ & $* * *$ \\
\hline Constant & $\begin{array}{r}3.016 \\
(0.087) \\
\end{array}$ & $* * *$ & $\begin{array}{r}3.055 \\
(0.077) \\
\end{array}$ & *** & $\begin{array}{r}2.754 \\
(0.110) \\
\end{array}$ & $* * *$ & $\begin{array}{r}2.864 \\
(0.066) \\
\end{array}$ & $* * *$ & $\begin{array}{r}2.849 \\
(0.069) \\
\end{array}$ & $* * *$ \\
\hline $\begin{array}{l}\text { Number of Observations } \\
\text { Wald } \mathrm{Chi}^{2} \\
\text { Psulo }\end{array}$ & $\begin{array}{r}21,398 \\
893.07 \\
0.050\end{array}$ & *** & $\begin{array}{r}32,368 \\
3443.220 \\
0.102\end{array}$ & $* * *$ & $\begin{array}{r}14,062 \\
1440.040\end{array}$ & $* * *$ & $\begin{array}{r}39,704 \\
2877.780\end{array}$ & $* * *$ & $\begin{array}{r}38,486 \\
2834.240\end{array}$ & *** \\
\hline $\begin{array}{l}\text { Pseudo } \mathrm{R}^{2} \\
\text { Dependent variable is the } \$ \text { a } \\
\text { are respectively the natural lo } \\
\text { for campaign } j . \text { Campaigns ir } \\
* * * \mathrm{p}<.01\end{array}$ & $\begin{array}{l}0.050 \\
\text { uted by } 1 \\
\text { gregate } \\
\text { catego }\end{array}$ & & $\begin{array}{l}\frac{0.102}{\text { to campaig }} \\
\text { social med } \\
\text { the base c }\end{array}$ & & $\begin{array}{l}0.117 \\
\text { ks) shares Media } \\
\text { standard }\end{array}$ & 1 ac & $\begin{array}{l}\frac{0.081}{\text { k) Shares a }} \\
\text { value of th } \\
\text { n parenthe }\end{array}$ & 5 & $\begin{array}{l}\frac{0.081}{\text { ding Target }} \\
\text { ng target re } \\
10, * * \mathrm{p}<.\end{array}$ & $\begin{array}{l}\$(\$) \\
\text { corde } \\
05\end{array}$ \\
\hline
\end{tabular}


Table 7: Poisson Regression Robustness Checks

Dependent Variable: Amount Contributed

\begin{tabular}{|c|c|c|c|c|c|c|c|c|c|c|c|c|c|c|}
\hline Model & $\begin{array}{c}\text { I } \\
\text { Commer } \\
\text { Only }\end{array}$ & & $\begin{array}{c}\text { II } \\
\text { Prosoci } \\
\text { Only }\end{array}$ & & $\begin{array}{c}\text { III } \\
\text { Creativ } \\
\text { Only }\end{array}$ & & $\begin{array}{c}\text { IV } \\
\text { Success } \\
\text { Only }\end{array}$ & & $\begin{array}{c}\mathrm{V} \\
\text { Unsucces } \\
\text { Only }\end{array}$ & & $\begin{array}{r}\text { VI } \\
\text { Includir } \\
\text { Photo }\end{array}$ & & $\begin{array}{c}\text { VII } \\
\text { Including } \\
\text { Outliers }\end{array}$ & \\
\hline Intrinsic Motivation $(=1)$ & -0.135 & & -0.149 & & -0.613 & & -0.314 & & -0.193 & & -0.307 & & -0.750 & \\
\hline Named $(=1)$ & $\begin{array}{r}(0.031) \\
0.120 \\
(0.022)\end{array}$ & $* * *$ & $\begin{array}{r}(0.046) \\
-0.070 \\
(0.048)\end{array}$ & & $\begin{array}{r}(0.050) \\
-0.085 \\
(0.019)\end{array}$ & $* * *$ & $\begin{array}{r}(0.025) \\
-0.014 \\
(0.016\end{array}$ & & $\begin{array}{r}(0.040) \\
-0.003 \\
-0.036\end{array}$ & & $\begin{array}{r}(0.021) \\
-0.013 \\
(0.015)\end{array}$ & & $\begin{array}{r}(0.058) \\
-0.332 \\
(0.068)\end{array}$ & $* * *$ \\
\hline Intrinsic Motivation * Named & $\begin{array}{r}-0.010 \\
(0.040)\end{array}$ & & $\begin{array}{r}(0.048) \\
0.144 \\
(0.053)\end{array}$ & $* * *$ & $\begin{array}{r}0.140 \\
(0.057)\end{array}$ & $* *$ & $\begin{array}{r}(0.010) \\
0.085 \\
(0.028)\end{array}$ & $* * *$ & $\begin{array}{r}(0.036) \\
0.042 \\
(0.045)\end{array}$ & & $\begin{array}{r}(0.015) \\
0.071 \\
(0.023)\end{array}$ & $* * *$ & $\begin{array}{r}(0.068) \\
0.365 \\
(0.071)\end{array}$ & $* * *$ \\
\hline Photo $(=1)$ & & & & & & & & & & & $\begin{array}{r}0.082 \\
(0.020)\end{array}$ & $* * *$ & & \\
\hline Ln Social Media Shares & $\begin{array}{l}-0.021 \\
(0.009)\end{array}$ & $* *$ & $\begin{array}{r}0.019 \\
(0.003)\end{array}$ & $* * *$ & $\begin{array}{r}0.082 \\
(0.011)\end{array}$ & $* * *$ & $\begin{array}{r}0.048 \\
(0.007)\end{array}$ & $* * *$ & $\begin{array}{r}0.012 \\
(0.004)\end{array}$ & *** & $\begin{array}{r}0.015 \\
(0.003)\end{array}$ & $* * *$ & $\begin{array}{r}0.049 \\
(0.006)\end{array}$ & $* * *$ \\
\hline Ln Funding Target (\$) & $\begin{array}{r}-0.028 \\
(0.177)\end{array}$ & ${ }^{*}$ & $\begin{array}{r}0.031 \\
(0.006)\end{array}$ & *** & $\begin{array}{r}0.019 \\
(0.008)\end{array}$ & $* *$ & $\begin{array}{r}0.077 \\
(0.007)\end{array}$ & *** & $\begin{array}{r}0.024 \\
(0.006)\end{array}$ & **** & $\begin{array}{r}0.052 \\
(0.004)\end{array}$ & ${ }^{* * *}$ & $\begin{array}{r}0.046 \\
(0.010)\end{array}$ & ${ }^{* * *}$ \\
\hline Project Category Controls & YES & & YES & & YES & & YES & & YES & & YES & & YES & \\
\hline Constant & $\begin{array}{r}4.046 \\
(0.162) \\
\end{array}$ & $* * *$ & $\begin{array}{r}3.415 \\
(0.079) \\
\end{array}$ & $* * *$ & $\begin{array}{r}3.348 \\
(0.084)\end{array}$ & $* * *$ & $\begin{array}{r}2.177 \\
(0.104)\end{array}$ & $* * *$ & $\begin{array}{r}3.593 \\
(0.079)\end{array}$ & $* * *$ & $\begin{array}{r}2.846 \\
(0.057)\end{array}$ & $* * *$ & $\begin{array}{r}3.004 \\
(0.121)\end{array}$ & $* * *$ \\
\hline $\begin{array}{l}\text { Number of Observations } \\
\text { Wald } \mathrm{Chi}^{2}\end{array}$ & $\begin{array}{r}13,728 \\
128.060\end{array}$ & $* * *$ & $\begin{array}{r}14,253 \\
426.130\end{array}$ & $* * *$ & $\begin{array}{r}25,150 \\
1291.030\end{array}$ & *** & $\begin{array}{r}39,844 \\
5229.910\end{array}$ & $* * *$ & $\begin{array}{r}13,922 \\
368.050\end{array}$ & $* * *$ & $\begin{array}{r}53,766 \\
4503.140\end{array}$ & $* * *$ & $\begin{array}{r}54,727 \\
1936.840\end{array}$ & $* * *$ \\
\hline Pseudo $\mathrm{R}^{2}$ & 0.013 & & 0.033 & & 0.086 & & 0.132 & & 0.028 & & 0.094 & & 0.103 & \\
\hline
\end{tabular}

Dependent variable is the $\$$ amount contributed by individual $i$ to campaion $j$. Ln Social Media (Facebook) Shares and Ln Funding Target (\$) are respectively the natural logarithm

of aggregate number of social media (Facebooks) shares and the $\$$ value of the fundraising target recorded for campaign $j$. All other variables are defined in Table 2. Categories

included in the 'Business Only' regression are Business and Technology. Categories included in the 'Prosocial Only' regression are Community, Education, Family Needs, Funerals,

Hopes \& Dreams, Medical, Non-Profit, Pets \& Animals, Sports and Volunteering. Categories included in the 'Creative Only' regression are Art, Design, Film \& Video, Gaming,

Music, Theater \& Dance and Writing. Base cases are indicated in italics. Robust standard errors are in parentheses. ${ }^{*} \mathrm{p}<.10,{ }^{* *} \mathrm{p}<.05,{ }^{* * *} \mathrm{p}<.01$ 
Figure 1: Distribution of Contribution Amounts

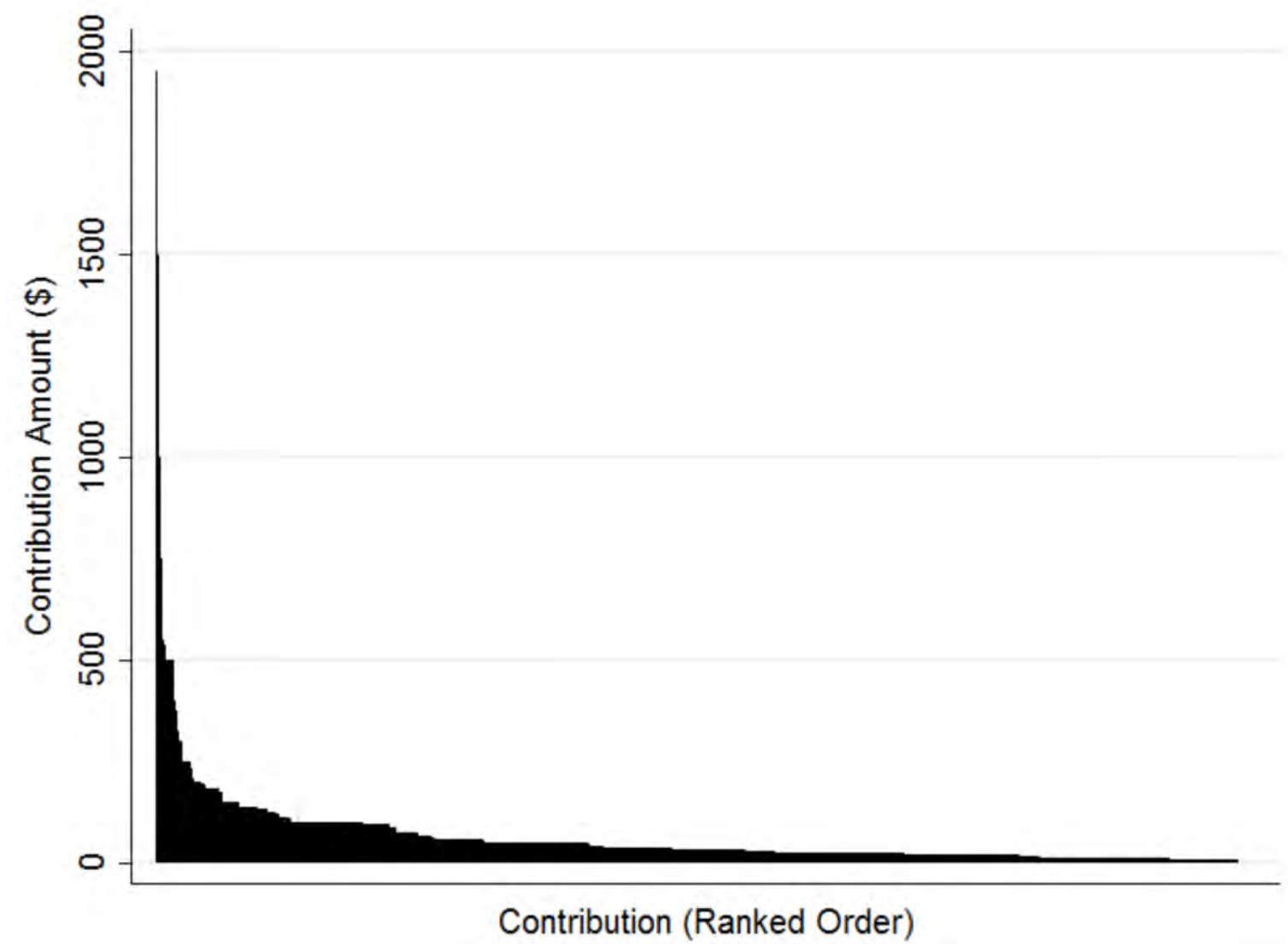

Note: This figure presents the distribution of individual contribution amounts received for campaigns in our dataset, ranked in order from

the highest contributions on the left to the lowest on the right. The highly skewed nature of this distribution demonstrates that campaigns on the fundanything.com platform tend to attract a small number of large contributions and a large number of small contributions. 
Figure 2: Proportion of Campaigns and Contributions by Category

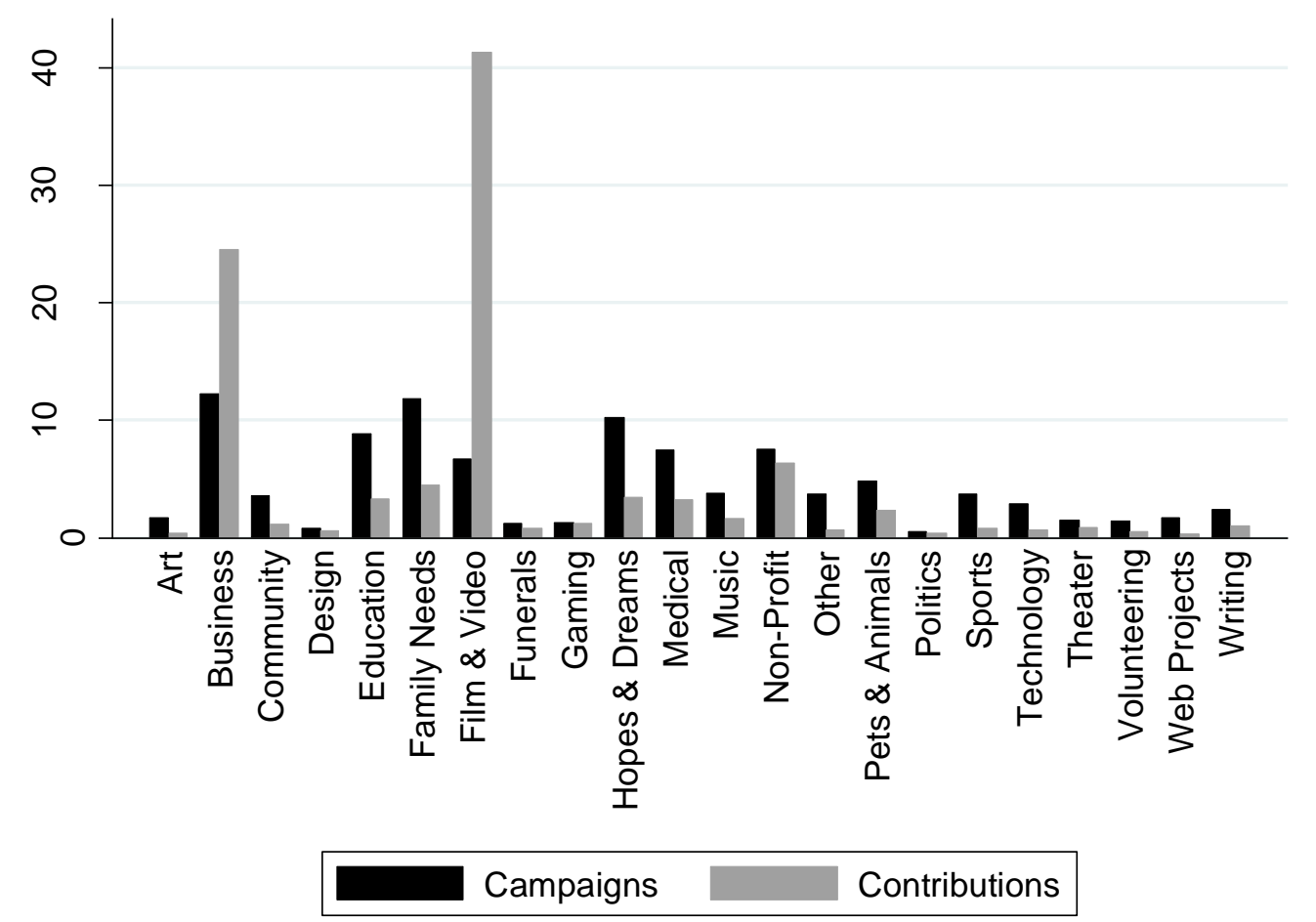

Note: This figure presents the proportion of campaigns in our dataset featuring in each fundraising category, as well as the proportion of

individual contributions received. The figure demonstrates that campaigns in the Flim \& Video and Business categories receive a

disproportionately high number of contributions relative to the number of campaigns featuring in said categories. 